\title{
STRATEGI PENGEMBANGAN BISNIS AIR MINERAL PT XYZ
}

\author{
Evan Sulistyo Gunawan \\ Program Studi Magister Manajemen Universitas Tarumanagara \\ evansulistyo7@gmail.com
}

\begin{abstract}
Untuk menghadapi persaingan, perusahaan perlu untuk pengambilan keputusan. Seperti mengambil keputusan stratejik dan responsif untuk mengevaluasi kekuatan, kelemahan, kesempatan dan hambatan yang terjadi di pasar.

Banyaknya pilihan strategi untuk tujuan jangka panjang perusahaan membuat semakin beragamnya cara pencapaian tujuan perusahaan itu sendiri. Seperti Strategic Position and Action Evalution (SPACE) Matrix, STP (Segmenting, Targeting, Positioning) dan Marketing Mix. Begitu juga strategi yang dilakukan PT XYZ terhadap tiga fokus tersebut. Keuntungan dari penggunaan strategi ini antara lain, dapat mengurangi biaya atau menaikkan produktivitas yang merupakan sasaran utama dari pendirian perusahaan. Strategi ekspansi ini juga dapat meningkatkan kepercayaan pelanggan dan atau pihak lain.
\end{abstract}

Keywords : Pengembangan Bisnis, Strategi industri air mineral dalam kemasan.

\section{PENDAHULUAN}

Lingkungan bisnis terus bergerak dan berubah. Situasi perekonomian yang tidak menentu, perubahan nilai-nilai sosial dan budaya, perkembangan teknologi yang terus berubah dapat memberikan pengaruh yang kuat terhadap keberadaan suatu usaha perusahaan.

\section{Pengertian Strategi}

Arti Penting Strategi

Menurut David (2011:16-17) strategi adalah sarana yang memiliki tujuan jangka panjang bagi perusahaan. Strategi bisnis mencakup ekspansi geografis, diversifikasi, akuisisi, pengembangan produk, penetrasi pasar, divestasi, likuidasi, dan usaha patungan (join venture).

Beberapa indikator tersebut dapat dijadikan acuan untuk pemetaan dengan menggunakan matriks SPACE yang terdiri dari kekuatan finansial (FS), stabilitas lingkungan (ES), keunggulan kompetitif (CA), dan kekuatan industri (IS). Dari matriks SPACE, dapat diketahui posisi perusahaan saat ini untuk kemudian dijadikan dasar dalam penetapan strategi yang tepat bagi perusahaan. 
Tabel Matriks Space PT XYZ

\begin{tabular}{|c|c|c|c|c|c|c|c|}
\hline \multirow{2}{*}{ POSISI STRATEGIK } & \multicolumn{6}{|c|}{ NILAI SKOR } & \multirow{2}{*}{ Total Skor } \\
\hline & 1 & 2 & 3 & 4 & 5 & 6 & \\
\hline \multicolumn{8}{|c|}{ INTERNAL } \\
\hline \multicolumn{8}{|l|}{$\begin{array}{l}\text { KEKUATAN } \\
\text { FINANSIAL (FS) }\end{array}$} \\
\hline a. ROI & & & & & 5 & & \\
\hline b. Leverage & & 2 & & & & & \\
\hline c. Likuiditas & & & 3 & & & & \\
\hline d. Modal Kerja & & & & & & 6 & \\
\hline Rata-Rata Nilai Skor & & & & & & & $5+2+3+6=16: 4=4$ \\
\hline \multicolumn{8}{|c|}{ EKSTERNAL } \\
\hline \multicolumn{8}{|l|}{$\begin{array}{l}\text { KEKUATAN INDUSTRI } \\
\text { (IS) }\end{array}$} \\
\hline a. Potensi Pertumbuhan & & 2 & & & & & \\
\hline $\begin{array}{l}\text { b. Pemanfaatan } \\
\text { Sumberdaya }\end{array}$ & & & & & 5 & & \\
\hline $\begin{array}{l}\text { c. Kemudahan Masuk ke } \\
\text { Industri }\end{array}$ & & & & & 5 & & \\
\hline d. Produktivitas & & & & 4 & & & \\
\hline Rata-Rata Nilai Skor & & & & & & & $2+5+5+4=16: 4=4$ \\
\hline \multicolumn{8}{|c|}{ INTERNAL } \\
\hline & -1 & -2 & -3 & -4 & -5 & $-\overline{6}$ & \\
\hline \multicolumn{8}{|l|}{$\begin{array}{l}\text { KEUNGGULAN } \\
\text { KOMPETITIF (CA) }\end{array}$} \\
\hline a. Pangsa Pasar & -1 & & & & & & \\
\hline b. Kualitas Produk & -1 & & & & & & \\
\hline c. Loyalitas Pelanggan & & -2 & & & & & \\
\hline $\begin{array}{l}\text { d. Pengendalian Pemasok } \\
\text { dan Distributor }\end{array}$ & & -2 & & & & & \\
\hline Rata-Rata Nilai Skor & & & & & & & $(-1)+(-1)+(-2)+(-2)=(-0): 4=(1,5)$ \\
\hline \multicolumn{8}{|c|}{ EKSTERNAL } \\
\hline \multicolumn{8}{|l|}{$\begin{array}{l}\text { STABILITAS } \\
\text { LINGKUNGAN (ES) }\end{array}$} \\
\hline a. Perubahan Tekhnologi & & -2 & & & & & \\
\hline b. Tekanan Persaingan & -1 & & & & & & \\
\hline $\begin{array}{l}\text { c. Keragaman } \\
\text { Permintaan }\end{array}$ & -1 & & & & & & \\
\hline d. Persaingan Harga & & & -2 & & & & \\
\hline Rata-Rata Nilai Skor & & & & & & & $(-2)+(-1)+(-1)+(-2)=(-0): 4=(1,5)$ \\
\hline \multicolumn{7}{|c|}{ Total Skor Sumbu Horizontal (CA+IS) } & $4+(1,5)=2,5$ \\
\hline \multicolumn{7}{|c|}{ Total Skor Sumbu Vertikal(FS+ES) } & $4+(1,5)=2,5$ \\
\hline
\end{tabular}




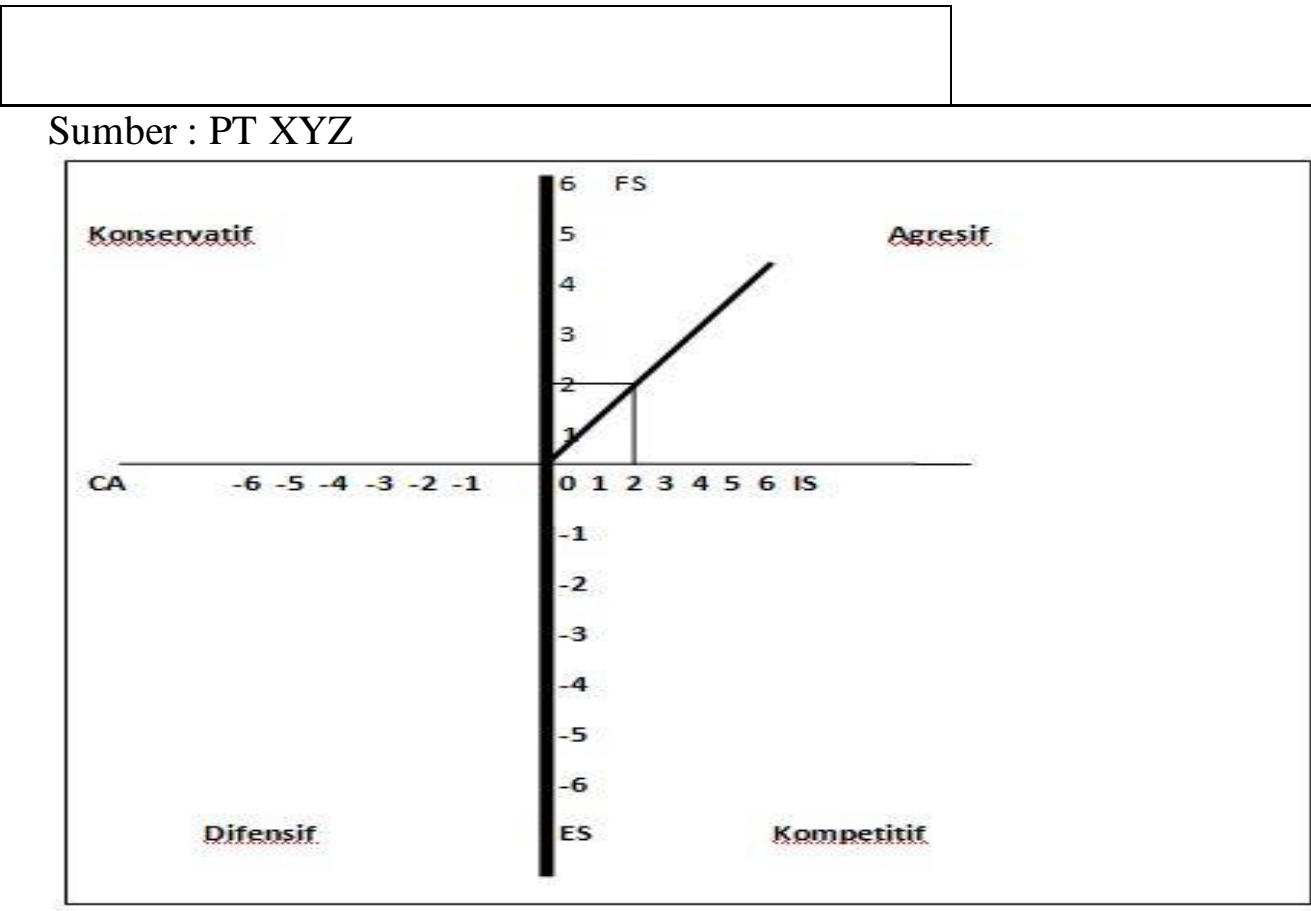

1. Marketing Strategy

a. $\quad$ STP (Segmenting, Targeting, Positioning)

Pengertian product (produk) menurut Kotler \& Armstrong (2012) adalah segala sesuatu yang dapat ditawarkan ke pasar untuk mendapatkan perhatian, dibeli, digunakan, atau dikonsumsi yang dapat memuaskan keinginan atau kebutuhan.

Ada tiga elemen dalam strategi pemasaran dalam PT XYZ yaitu segmentation, targeting dan positioning.

1. Segmenting

PT XYZ merupakan perusahaan yang menyalurkan air mineral dalam kemasan. Persaingan yang semakin ketat antar penjual dengan produk sejenis membuat PT XYZ harus melakukan segmentasi pasar untuk mengetahui segmen mana yang akan dituju dalam memasarkan produk.

2. Targeting

Target dari produk yang ditawarkan oleh PT XYZ adalah keseluruhan kalangan masyarakat dari berbagai usia, suku dan budaya yang tentunya membutuhkan produk air mineral dalam kemasan. Dalam upaya menjangkau konsumen dan calon pelanggan, PT XYZ melakukan hal ini tanpa adanya batasan konsumen dengan tujuan agar dapat meningkatkan penjualan.

Jangkauan yang dilakukan dimulai dari Ibukota Jakarta sendiri yang merupakan lokasi usaha dari PT XYZ sampai dengan berbagai kota di seluruh Indonesia yang bisa dicapai melalui akses internet. Dalam memilih strategi yang digunakan dalam market targeting maka dapat dipilh berdasarkan: Mass Market, Niche Market, atau Growth Market.

\section{Positioning}

Positioning merupakan langkah terakhir yang sangat menentukan

keberhasilan dalam strategi pemasaran.

Positioning yang dilakukan PT XYZ adalah positioning berdasarkan pengguna produk. Pendekatan ini hampir sama dengan targeting dimana lebih menekankan pada siapa pengguna produk. 


\section{b. $\quad$ Entrepreneurial Marketing Mix}

Bauran pemasaran yang akann digunakan sebagai program pemasaran PT XYZ adalah Entrepreneurial Marketing Mix yang terdiri dari 4P, yaitu: Practices, Purpose, Person dan Process. Entrepreneurial Marketing Mix

1. Practices

Menurut Philip Kotler dan Gery Amstrong $(2012 ; 76)$ promosi adalah “aktivitas yang mengkomunikasikan keunggulan produk dan membujuk konsumen sasaran untuk membelinya".

PT XYZ merupakan sebuah usaha yang bergerak di bidang penjualan minuman sehat. Terdapat beberapa ide pemasaran yang dapat dilakukan, diantaranya:

a. Mendirikan 10-15 outlet di mal-mal dan pusat olahraga dan kesehatan di kawasan Ibukota Jakarta.

b. Memasang iklan di blog-blog diet dan kesehatan di internet

c. Melakukan guerilla promotion. Salah satunya dengan menempatkan QR-Code dengan desain menarik di berbagai lokasi baik di dunia maya maupun di dunia nyata. Keunikan dan perbedaan ini juga dapat membantu Anda dalam membangun brand, karena orang cenderung ingat dengan suatu hal yang unik.

\section{Purpose}

Tujuan dari Practices yang direncanakan diatas adalah untuk menginformasikan dan memperkenalkan mengenai manfaat dari produk serta mengajak sebanyak mungkin pelanggan untuk membeli produk dari PT XYZ. Melalui kegiatan pemasaran ini diharapkan dapat memberikan solusi bagi kebutuhan calon pelanggan. Kebutuhan yang diberikan adalah produk minuman alami yang sehat dengan harga yang lebih terjangkau.

\section{Person}

Pemilik dan karyawan dari PT XYZ banyak pengalaman di bidang pemasaran, PT XYZ juga membutuhkan tenaga pemasaran yang berpengalaman untuk merencanakan dan menetapkan strategi pemasaran yang telah direncanakan oleh penulis. Pemasaran yang baik dalam suatu perusahaan berdampak baik pada kemajuan perusahaan tersebut.

4. Process

PT XYZ memiliki proses kedepan untuk mengembangkan usahanya. pengembangan usaha diantaranya adalah Membuat kemasan air mineral dalam kemasan dalam bentuk mini untuk memenuhi kebutuhan kebutuhan dalam pasar industri catering makanan dalam kemasan boks.

\section{Human Resource Development Strategy}

Dessler (2007:58) "Manajemen Sumber Daya Manusia merupaka kebijakan dan praktek menentukan aspek "manusia" atau SDM dalam posisi manajemen, termasuk merekrut, menyaring, melatih, memberi penghargaan, dan penilaian.

Pada dasarnya kegitan pelatihan yang dibutuhkan perusahaan dan dilaksanakan oleh PT. XYZ dibagi kedalam tiga jenis meliputi :

1. Skill (Keterampilan) :

Supaya lebih efektif pada pelaksanaan pelatihan di PT. XYZ. Pelatihan yang meliputi skill di PT. XYZ yaitu:

a. Bidang Manager : pengelolahan karyawan dan operasional

b. Bidang Prime customer : Promosi produk dan fasilitas perusahaan dan pengelompokan pelanggan bisnis

c. Bidang Personal Costomer : Pengelompokan pelanggan residensial

d. Bidang Direct Chanel: Pelayanan Pelanggan

2. Knowledge (pengetahuan)

Adapun materi atau metode yang disampaikan untuk jenis pelatihan ini berupa : Ceramah, Diskusi dan teori, sedangkan praktek diberikan hanya sebagian- 
kecil saja atau disesuaikan dengan kebutuhan, terutama menyangkut hal-hal yang baru (inovasi).

3. Attitude (Sikap dan Prilaku)

Pelatihan yang dilaksanakan oleh PT. XYZ bersifat peningkatan Attitude (sikap dan prilaku) sifatnya soft sehingga sulit untuk mengukur keberhasilannya, namun demikian penulis melihat pada unit customer care, mampu melakukan berbagai cara pelatihan agar seorang karyawan dapat merubah sikap dan perilakunya kearah yang positif, yang idealnya lagi bila penyerapan dan transfer ilmu pengetahuan dan wawasannya dapat diaplikasikan ditempat tugasnya masing-masing karyawan PT. XYZ Jenis pelatihan yang dilakanakan oleh unit customer care biasanya berupa pembinaan fisik, mental dan spiritual.

\section{Strategi Manajemen Operasional PT XYZ}

Pengertian manajemen operasional menurut Draft (2006:216), adalah bidang manajenyang mengkhususkan pada produksi barang, serta menggunakan alatalat dan teknik-teknik khusus untuk memecahkan masalah-masalah produksi.

Perusahaan yang terus memperhatikan perkembangan kinerjanya dan berupaya untuk meningkatkan kinerja tersebut memiliki peluang mencapai posisi persaingan yang baik maka sebenarnya perusahaan telah memiliki modal yang kuat untuk terus bersaing dengan perusahan lain (Meike Supranoto,10 September 2010).

Berikut Alur kerja pendistribusian Manajemen Operasional PT XYZ :

a. Melakukan kontrol stok barang untuk estimasi penjualan

b. Permintaan produksi barang untuk estimasi penjualan satu bulan kedepan

c. Melakukan order barang ke pabrik untuk buffer stock penjualan selama satu minggu

d. Melakukan kontrol pengiriman barang guna menjaga service level ke pelanggan

e. Melakukan kontrol penjualan salesman agar distribusi berjalan merata

f. Melakukan kontrol faktur apakah sudah sesuai dengan order yang telah dilakukan salesman.

g. Melakukan kontrol program yang sedang berjalan di pasar agar apa yang di berikan oleh perusahaan kepada konsumen dapat diterima dengan baik.

h. Melakukan kontrol piutang secara garis besar agar kegiatan operasional perusahaan berjalan lancar.

i. Mengevaluasi kinerja sumber daya manusia per periode sesuai dengan yang di hasilkan karyawan tersebut.

j. Melaporkan hasil kegiatan operasional perusahaan secara berkala kepada pimpinan perusahaan

4. Strategi manajemen keuangan

Ray (2004) menjelaskan bahwa perusahaan melakukan diversifikasi dengan motivasi untuk mengatasi kompleksitas persaingan yaitu membangun kekuatan financial dan efisiensi biaya.

Pengembangan usaha adalah "Tugas dan proses persiapan analitis tentang peluang pertumbuhan potensial, dukungan dan pemantauan pelaksanaan peluang pertumbuhan usaha, tetapi tidak termasuk keputusan tentang strategi dan implementasi dari peluang pertumbuhan usaha" Hendro (2011, p512)

Selanjutnya untuk mengetahui apakah perencanaan keuangan PT XYZ benarbenar dapat mencapai tujuan tersebut, maka dapat dilakukan evaluasi dan- 
analisis rencana keuangan dari $\mathrm{XYZ}$ antara lain cara perhitungannya dan analisisnya sebagai berikut:

1.Dana Perusahaan

PT XYZ membutuhkan dana untuk tetap beroperasi, karena kegagalan dalam membayar pemasok dapat membuat bangkrutnya usaha. PT XYZ harus dapat membedakan dua jenis pengeluaran yaitu:

a. Pengeluaran Jangka Pendek (Short Term atau Operatinge expenditures)

b. Pengeluran Jangka Panjang (Long Term atau Capital expenditures)

\subsection{Kesimpulan}

Kesimpulan berdasarkan analisis Strategic Position And Action Evaluation (SPACE Matrix) yang telah dilakukan pada penelitian pada PT XYZ, dapat disimpulkan bahwa posisi PT XYZ berada pada kuadran agresif yang mengindikasikan bahwa perusahaan tersebut berada pada posisi yang terbaik untuk menggunakan kekuatan internal,. Hal ini berarti strategi yang tepat adalah strategi ekspansi (growth). Strategi yang harus dilakukan oleh PT XYZ antara lain:

a. PT XYZ lebih meningkatkan penjualan dengan memproduksi produk baru, menambah mutu dan kualitas produk sehingga dapat meningkatkan keuntungan perusahaan.

b. PT XYZ lebih memfokuskan pada konsumen yang memiliki gaya hidup sehat sebagai dasar untuk peluncuran produk baru.

\subsection{Saran}

Berdasarkan kesimpulan tersebut, maka dapat disarankan hal-hal sebagai berikut, perusahaan hendaknya dapat memilih strategi yang sesuai. PT XYZ dapat menerapkan strategi ekspansi (growth) dan meningkatkan pada kekuatan finansial (misalnya mengurangi tingginya leverage perusahaan) sehingga kinerja perusahaan dapat meningkat, serta melakukan ekspansi usaha untuk menambah pangsa pasar (misalnya merambah pasar AMDK internasional).

Dilihat dari tingkat kebutuhan, segmentasi pasar berdasarkan umur, jenis pekerjaan, dan semua jenis pasar dari tradisional, modern, hingga ke segmentasi pasar perhotelan kantor dan perumahan semua membutuhkan air mineral sebagai kebutuhan dasar.

\section{DAFTAR PUSTAKA}

David, Fred R (2011). Strategic Management: ConcePT (12th Edtiton), New Jersey, USA: Pearson Education Inc.

Supranoto, Mieke (2010). Artikel 10 September 2010

Hendro (2011). Dasar - Dasar Kewirausahaan, Erlangga, Jakarta.

Kotler, P. \& Armstrong, G. (2013). Principles of Marketing. 15th Edition. New Jersey: Prentice Hall

Kotler, Philip \& Keller, Kevin Lane. (2012). Marketing Management. (14th edition). New Jersey: Prentice Hall.

Mathis, Robert L. \& Jackson, John H. (2010). Human Resource Management. Tenth Edition: Maso, USA: South-Western Cengage Learning

Pearce II, John A \& Richard B. Robinson, JR. (2011). Strategic Management: Formulation, Implementation and Control (10th edition), New York:McGraw-Hill.

Dafl, L. Richard \& Marcic, Dorothy. (2009). Understanding Management, Mason Ohio:South-Western Cemgage Learning. 
David, Fred R (2011). Strategic Management: ConcePT (12th Edtiton), New Jersey, USA: Pearson Education Inc.

Armstrong, Gary \& Kotler, Philip. (2012). Principles of Marketing (14th edition), New Jersey: Prentice Hall. Person Education, Inc., 
